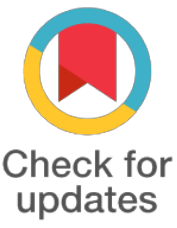

*For correspondence:

hungnguyenphu@gmail.com

Competing interests: The authors declare that no competing interests exist.

Received: 2017-06-23

Accepted: 2017-07-10

Published: 2017-09-05

Copyright The Author(s) 2017. This article is published with open access by BioMedPress (BMP)

This article is distributed under the terms of the Creative Commons Attribution License (CC-BY 4.0) which permits any use, distribution, and reproduction in any medium, provided the original author(s) and the source are credited.

\section{All-trans retinoic acid targets gastric cancer stem cells and inhibits patient-derived gastric carcinoma tumor growth}

\author{
P H Nguyen, J Giraud, C Staedel, L Chambonnier, P Dubus, E Chevret, H \\ Boeuf, X Gauthereau, B Rousseau, M Fevre, I Soubeyran, G Belleannée, S \\ Evrard, D Collet, F Mégraud and C Varon
}

Faculty of Biotechnology Thai Nguyen Universtiy of Sciences, Thai Nguyen, Vietnam

\title{
Keywords
}

Cancer stem cells, all trans retinoic acid, gastric cancer

\section{Funding}




\section{References}

1. Nguyen, P.H., Giraud, J., Staedel, C., Chambonnier, L., Dubus, P., Chevret, E., Bœuf, H., Gauthereau, X., Rousseau, B., Fevre, M., et al. (2016). All-trans retinoic acid targets gastric cancer stem cells and inhibits patient-derived gastric carcinoma tumor growth. Oncogene.

2. Nguyen, P.H., Giraud, J., Chambonnier, L., Dubus, P., Wittkop, L., Belleannée, G., Collet, D., Soubeyran, I., Evrard, S., Rousseau, B., et al. (2017). Characterization of Biomarkers of Tumorigenic and Chemoresistant Cancer Stem Cells in Human Gastric Carcinoma. Clin. Cancer Res. Off. J. Am. Assoc. Cancer Res. 23, 1586-1597. 